In cooperation with the Kentucky Department of Agriculture

\title{
Concentrations of Nutrients, Pesticides, and Suspended Sediment in the Karst Terrane of the Sinking Creek Basin, Kentucky, 2004
}

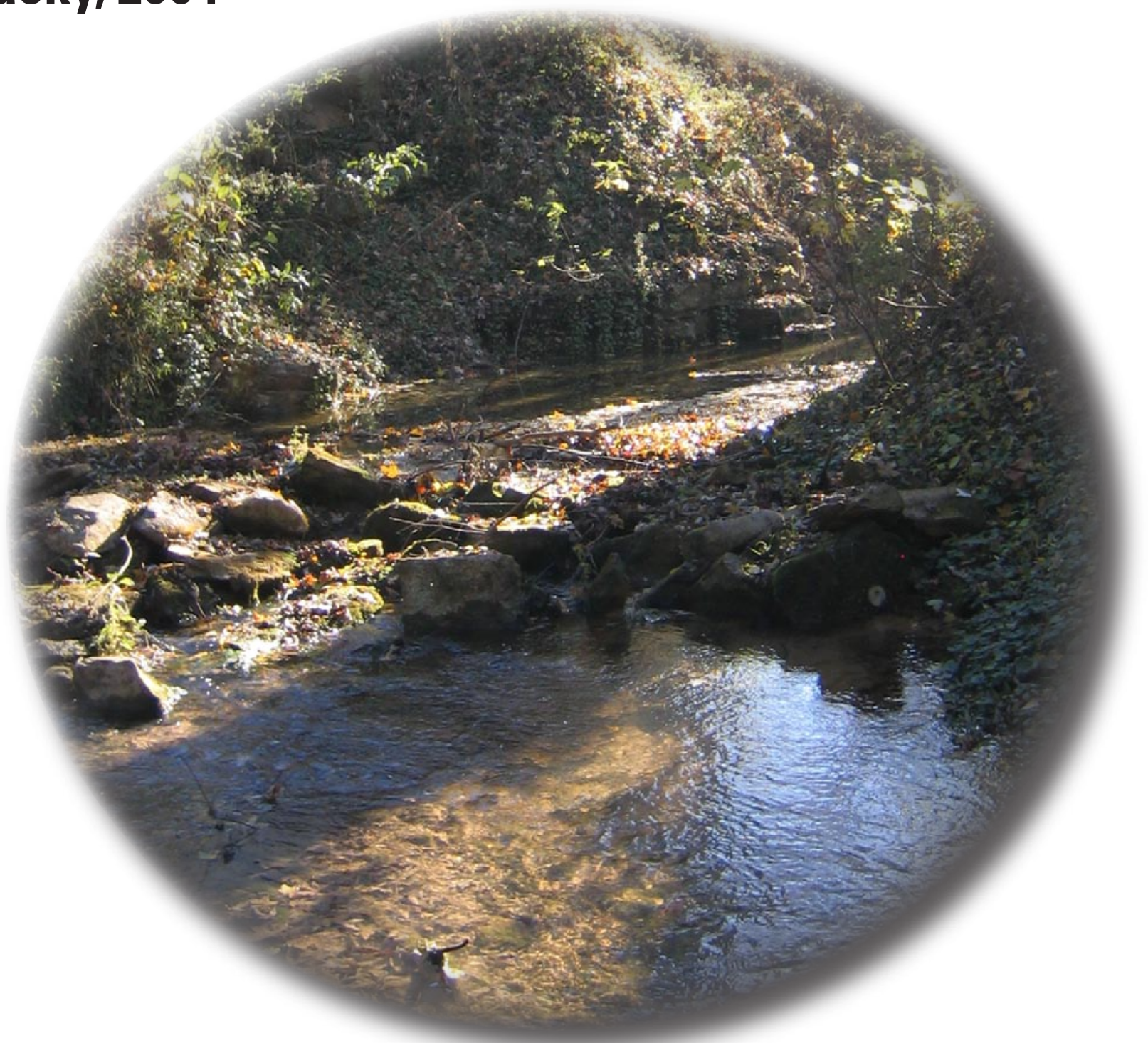

Open-File Report 2006-1091 
Cover Photograph. Karst window at Big Spring, Kentucky. (Photograph by A.S. Crain, U.S. Geological Survey, October 2004). 


\section{Concentrations of Nutrients, Pesticides, and Suspended Sediment in the Karst Terrane of the Sinking Creek Basin, Kentucky, 2004}

By Angela S. Crain

In cooperation with the Kentucky Department of Agriculture

Open-File Report 2006-1091 


\section{U.S. Department of the Interior \\ Gale A. Norton, Secretary \\ U.S. Geological Survey \\ P. Patrick Leahy, Acting Director}

\section{U.S. Geological Survey, Reston, Virginia: 2006}

For product and ordering information:

World Wide Web: http://www.usgs.gov/pubprod

Telephone: 1-888-ASK-USGS

For more information on the USGS--the Federal source for science about the Earth, its natural and living resources, natural hazards, and the environment:

World Wide Web: http://www.usgs.gov

Telephone: 1-888-ASK-USGS

Any use of trade, product, or firm names is for descriptive purposes only and does not imply endorsement by the U.S. Government.

Although this report is in the public domain, permission must be secured from the individual copyright owners to reproduce any copyrighted materials contained within this report.

The U.S. Geological Survey does not discriminate on the basis of race, color, national origin, sex, age, religion or disability and provides on request, reasonable accommodations including auxiliary aids and services necessary to afford an individual with a disability an equal opportunity to participate in all services, programs, and activities. These materials can be provided in alternative format to any individual with a disability. Printed with Federal Section 319(h) Funds.

Suggested citation:

Crain, Angela S., 2006, Concentrations of Nutrients, Pesticides, and Suspended Sediment in the Karst Terrane of the Sinking Creek Basin, Kentucky, 2004: U.S. Geological Survey Open-File Report 2006-1091, 15 p. 


\section{Contents}

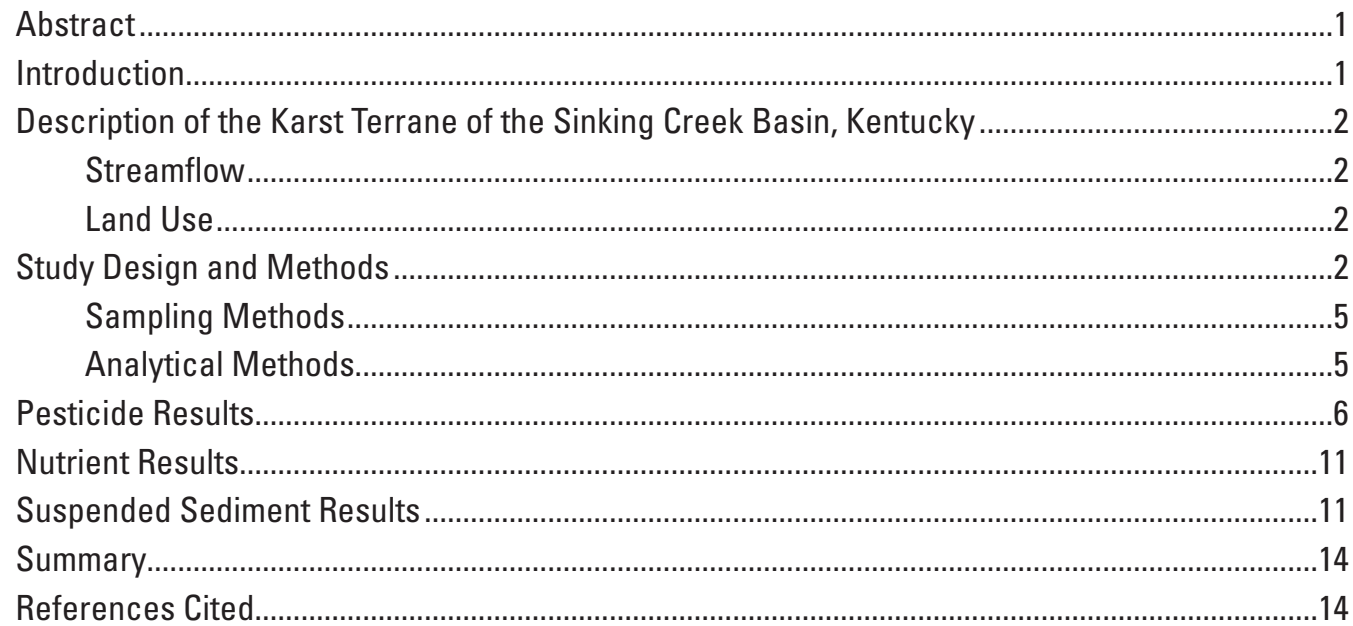

\section{Figures}

1. Map showing the location of the surface- and ground-water sampling sites in the karst terrane of the Sinking Creek Basin, Kentucky, study area

2. Map showing land cover in the karst terrane of the Sinking Creek Basin, Kentucky, study area, 2001

3-6. Graphs showing:

3. Pesticides most frequently detected in all samples collected at seven sites in the karst terrane of the Sinking Creek Basin, Kentucky, 2004

4. Concentrations of atrazine, metolachlor, and simazine at the seven sampling sites in the karst terrane of the Sinking Creek Basin, Kentucky, study area, 2004 .............10

5. Concentrations of nitrite plus nitrate, total phosphorus, and orthophosphorus at the seven sampling sites in the karst terrane of the Sinking Creek Basin, Kentucky, study area, 2004.

6. Concentrations of suspended sediment at the seven sampling sites in the karst terrane of the Sinking Creek Basin, Kentucky, study area, 2004

\section{Tables}

1. Surface- and ground-water sites sampled in the karst terrane of the Sinking Creek Basin, Kentucky, 2004.

2. Statistical summary of the detected herbicides and insecticides in samples collected in the karst terrane of the Sinking Creek Basin, Kentucky, April-November 2004, laboratory reporting limits, drinking-water standards, and aquatic-life criteria.

3. Statistical summary of concentrations of nitrogen, phosphorus, and sediment in the karst terrane of the Sinking Creek Basin, Kentucky, April-November 2004. 


\section{Conversion Factors}

Inch/Pound to SI

\begin{tabular}{|c|c|c|}
\hline Multiply & By & To obtain \\
\hline \multicolumn{3}{|c|}{ Length } \\
\hline inch (in.) & 2.54 & centimeter $(\mathrm{cm})$ \\
\hline inch (in.) & 25.4 & millimeter $(\mathrm{mm})$ \\
\hline millimeter $(\mathrm{mm})$ & 0.03937 & inch (in.) \\
\hline \multicolumn{3}{|c|}{ Area } \\
\hline acre & 4,047 & square meter $\left(\mathrm{m}^{2}\right)$ \\
\hline acre & 0.004047 & square kilometer $\left(\mathrm{km}^{2}\right)$ \\
\hline square mile $\left(\mathrm{mi}^{2}\right)$ & 2.590 & square kilometer $\left(\mathrm{km}^{2}\right)$ \\
\hline \multicolumn{3}{|c|}{ Mass } \\
\hline pound, avoirdupois (lb) & 0.4536 & kilogram (kg) \\
\hline
\end{tabular}

Temperature in degrees Celsius $\left({ }^{\circ} \mathrm{C}\right)$ may be converted to degrees Fahrenheit $\left({ }^{\circ} \mathrm{F}\right)$ as follows:

${ }^{\circ} \mathrm{F}=\left(1.8 \times^{\circ} \mathrm{C}\right)+32$

Concentrations of chemical constituents in water are given either in milligrams per liter (mg/L) or micrograms per liter $(\mu \mathrm{g} / \mathrm{L})$.

\section{Abbreviations}

D0 - dissolved oxygen

$E W I$ - equal width increment

GC/MS - gas chromatography/mass spectrometry

KWSC - Kentucky Water Science Center

$\mathrm{mL}$ - milliliter

$\mathrm{MCL}$ - maximum contaminant level

MDL - method detection limit

$M R L$ - method reporting limit

NPS - nonpoint-source pollution

NWQL - National Water Quality Laboratory

$\mu \mathrm{m}$ - micrometer 


\title{
Concentrations of Nutrients, Pesticides, and Suspended Sediment in the Karst Terrane of the Sinking Creek Basin, Kentucky, 2004
}

\author{
By Angela S. Crain
}

\section{Abstract}

Water samples were collected in streams and springs in the karst terrane of the Sinking Creek Basin in 2004 as part of study in cooperation with the Kentucky Department of Agriculture. A total of 48 water samples were collected at 7 sites (4 springs, 2 streams, and 1 karst window) from April through November 2004. The karst terrane of the Sinking Creek Basin (also known as Boiling Spring Basin) encompasses about 125 square miles in Breckinridge County and portions of Meade and Hardin Counties in Kentucky.

Fourteen pesticides were detected of the 52 pesticides analyzed in the stream and spring samples. Of the 14 detected pesticides, 12 were herbicides and 2 were insecticides. The most commonly detected pesticides—atrazine, simazine, metolachlor, and acetochlor-were those most heavily used on crops during the study. Atrazine was detected in 100 percent of all samples; simazine, metolachlor, and acetochlor were detected in more than 35 percent of all samples. The pesticidetransformation compound, deethylatrazine, was detected in 98 percent of the samples. Only one nonagricultural herbicide, prometon, was detected in more than 30 percent of the samples. Malathion, the most commonly detected insecticide, was found in 4 percent of the samples, which was followed by carbofuran (2 percent).

Most of the pesticides were present in low concentrations; however, atrazine was found in springs exceeding the U.S. Environmental Protection Agency's (USEPA) standards for drinking water. Atrazine exceeded the USEPA's maximum contaminant level 2 times in 48 detections.

Concentrations of nitrate greater than 10 milligrams per liter $(\mathrm{mg} / \mathrm{L})$ were not found in water samples from any of the sites. Concentrations of nitrite plus nitrate ranged from 0.21 to $3.9 \mathrm{mg} / \mathrm{L}$ at the seven sites. The median concentration of nitrite plus nitrate for all sites sampled was $1.5 \mathrm{mg} / \mathrm{L}$. Concentrations of nitrite plus nitrate generally were higher in the springs than in the main stem of Sinking Creek.

Forty-two percent of the concentrations of total phosphorus at all seven sites exceeded the USEPA's recommended maximum concentration of $0.1 \mathrm{mg} / \mathrm{L}$. The median concentration of total phosphorus for all sites sampled was $0.09 \mathrm{mg} / \mathrm{L}$. The highest median concentrations of total phosphorus were found in the springs. Median concentrations of orthophosphate followed the same pattern as concentrations of total phosphorus in the springs. Concentrations of orthophosphate ranged from $<0.006$ to $0.192 \mathrm{mg} / \mathrm{L}$.

Concentrations of suspended sediment generally were low throughout the basin; the median concentration of suspended sediment for all sites sampled was $23 \mathrm{mg} / \mathrm{L}$. The highest concentration of suspended sediment $(1,486 \mathrm{mg} / \mathrm{L})$ was measured following a storm event at Sinking Creek near Lodiburg, Ky.

\section{Introduction}

Nearly 1 billion pounds of pesticides are used annually in the United States (Barbash and Resek, 1997). About 80 percent of pesticides are used for agricultural purposes, but pesticides also are used for industrial, commercial, and household purposes. Although the use of pesticides has resulted in increased crop production and other benefits, it has raised concerns about potential adverse effects on the environment and human health. Nutrients, primarily nitrogen and phosphorus compounds, occur naturally, but also are applied to land in the form of commercial fertilizers and manure to enhance the production of plant growth. Concentrations of suspended sediment are affected by natural conditions (soil erosion and streambed resuspension) and by human activities (construction, logging, and certain agricultural practices). Suspended sediment plays a major role in the transport and fate of contaminants because contaminants may sorb onto the surface of the suspended sediments and be transported and deposited into other areas downstream. Excess pesticides, nutrients, and suspended sediment in the environment can cause a variety of adverse ecological and human-health effects.

Despite advances in our knowledge and understanding of the sources of agriculturally derived nonpoint-source pollu- 
tion (NPS) and the development of best-management practices intended to reduce NPS pollution, both surface and ground water continue to receive increased loadings of pesticides, nutrients, and sediment (Becher and others, 2000; Goolsby and Battaglin, 1997; and Schilling and Thompson, 2000). The effect on water quality by agricultural activities, habitat modification, and urbanization in areas of karst terrane are important considerations for resource management in Kentucky.

Pesticides, nutrients, and sediment are frequently detected in shallow ground water and are a threat to contribute to the degradation of drinking water because of erosion and leaching. Resource managers often are faced with difficult decisions concerning development of land and the protection of ground water from these contaminants. Understanding the role of best-management practices in protecting shallow ground water from human-induced activities (construction, logging, and certain agricultural activities) is fundamental to developing and implementing sound land-use policies. This is the case faced by resource managers in the karst terrane area of the Sinking Creek Basin, as well as other karst regions of Kentucky.

The purpose of this report is to describe the methods and procedures used during sample collection and analysis and present the concentrations of select pesticides, nutrients, and suspended sediment in the karst terrane of the Sinking Creek Basin from the first of 3 years of sample collection. A final report presenting all 3 years of water-quality-data collection should be available in late 2007. Samples were collected from two Sinking Creek stream sites, four springs, and one karst window in the study area.

\section{Description of the Karst Terrane of the Sinking Creek Basin, Kentucky}

The karst terrane of the Sinking Creek Basin (also known as the Boiling Spring Basin) encompasses about $125 \mathrm{mi}^{2}$ (fig. 1). Water quality throughout the basin is directly affected by natural (geology, climate, and soils) and human (population and land use) factors. The karst terrane of the Sinking Creek Basin has a high hydrogeologic sensitivity rating indicating it is highly vulnerable to effects from runoff because much of the area is underlain by karst. The hydrogeologic sensitivity rating of an area is defined as the potential ease and speed with which a contaminant can move into and within a ground-water system (Ray and others, 1994). Ground water from the subsurface channels comes out at several natural springs and karst windows and flows directly into Sinking Creek within the karst terrane of the Sinking Creek Basin. The Sinking Creek Basin is listed as a target priority watershed by the Kentucky Division of Water because of impairments to water resources in the basin. These impairments include siltation, nutrients, pathogens, organic enrichment (low dissolved oxygen (DO)), and habitat modifications. (Kentucky Division of Water, 2005).

\section{Streamflow}

Overland flow (direct surface runoff) and ground-water discharge are the major sources of streamflow in the Sinking Creek Basin. Another source of flow to streams in the Sinking Creek Basin is interflow. Interflow is that part of the subsurface flow that moves at shallow depths and reaches the surface channels in a short period of time. During a storm, interflow slowly increases until the end of the storm, then gradually decreases (Viessman and others, 1989, p. 171).

Mean annual precipitation for Irvington, Ky., is about 45 in. (National Oceanic and Atmospheric Administration, 1999). Spring and summer tend to receive the greatest monthly precipitation amounts, which are usually associated with thunderstorms.

\section{Land Use}

Streams, sinkholes, and springs in the karst terrane of the Sinking Creek Basin drain a diverse landscape of forest, agricultural areas, and developed areas around Irvington. Agricultural land uses represent about 48 percent of the study area (fig. 2). Most of the agricultural land (37 percent) is pasture; the remaining 11 percent is used for corn, soybeans, wheat, hay, and tobacco production. Soybeans are the principal row crop harvested in the basin followed by corn. In 2003, about 53,500 acres of soybeans were harvested, and about 45,300 acres of corn were harvested for seed, grain, silage, or sweet corn (Kentucky Agricultural Statistics Service, 2004).

Forested land represents about 47 percent of the karst terrane in the Sinking Creek Basin; urban areas account for about 4 percent of the karst terrane in the basin. Irvington, with a population of approximately 1,300 , is the most heavily populated community in the karst terrane of the Sinking Creek Basin (U.S. Census Bureau, 2001).

\section{Study Design and Methods}

Sampling sites in the karst terrane of the Sinking Creek Basin were selected to assess the spatial and seasonal variability of nutrients, pesticides, and suspended sediment in areas of mixed land use and different types of agricultural land. Samples were collected on two Sinking Creek main stem sites (Sinking Creek at Rosetta and Sinking Creek near Lodiburg); four springs (Big Spring, Flat Rock Spring, Fiddle Spring, and Boiling Spring); and one karst window (Ross Karst Window) (table 1). Water-quality and suspended-sediment samples were collected monthly from April through November 2004 at all sites. Water-quality and suspended-sediment samples also were collected at each of these sites during high-flow events on two occasions. A total of 48 samples were collected for nutrient, suspended sediment, and pesticide analysis at the sites. 


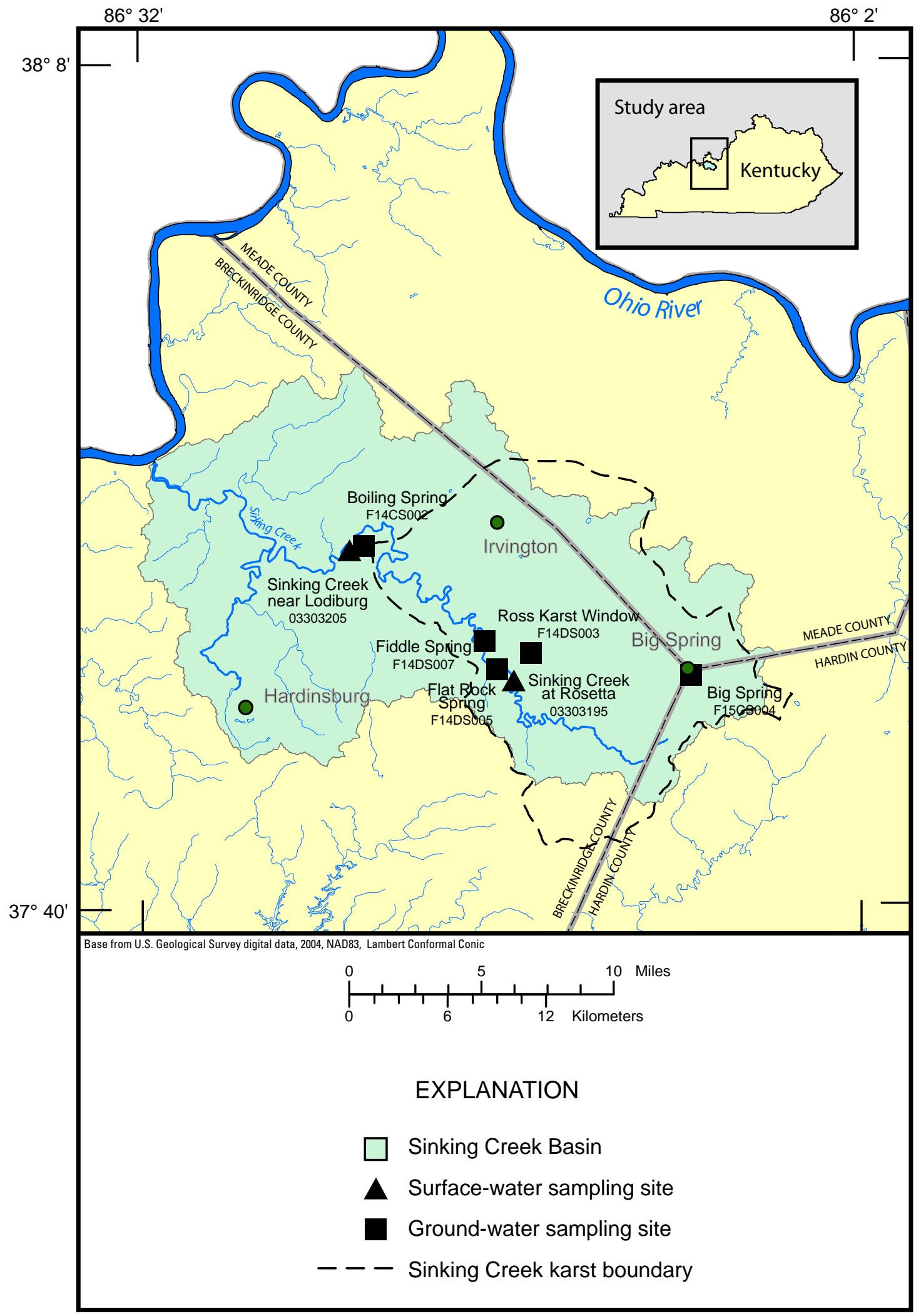

Figure 1. Location of the surface- and ground-water sampling sites in the karst terrane of the Sinking Creek Basin, Kentucky, study area. 


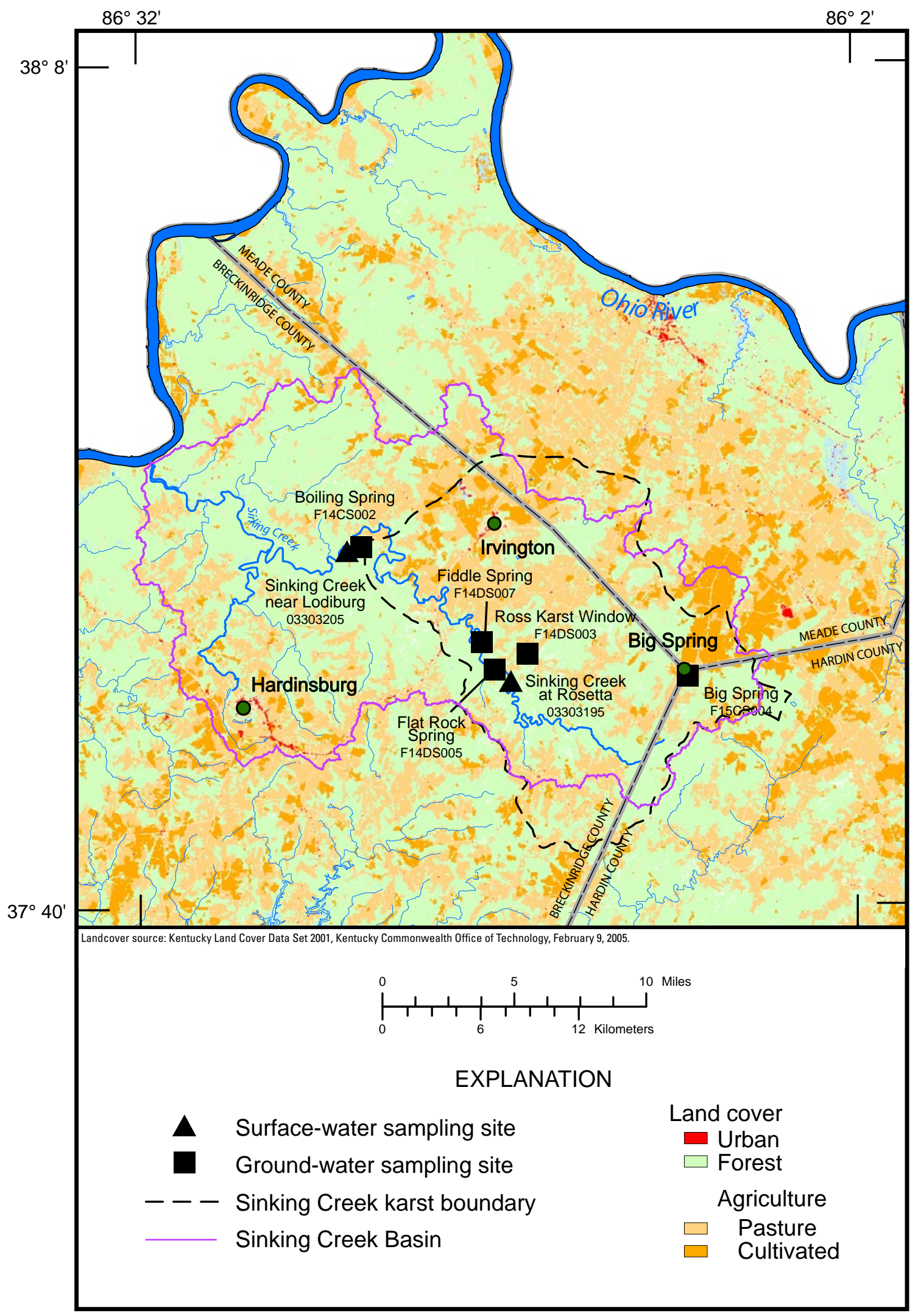

Figure 2. Land cover in the karst terrane of the Sinking Creek Basin, Kentucky, study area, 2001. 
Table 1. Surface- and ground-water sites sampled in the karst terrane of the Sinking Creek Basin, Kentucky, 2004.

[USGS, U.S. Geological Survey; DMS, degrees, minutes, seconds; mi², square miles; GW, ground water; --, not available; Ky., Kentucky; SW, surface water]

\begin{tabular}{|c|c|c|c|c|c|}
\hline $\begin{array}{c}\text { USGS station } \\
\text { number }\end{array}$ & USGS site name & $\begin{array}{c}\text { Type } \\
\text { of } \\
\text { site } \\
\end{array}$ & $\begin{array}{l}\text { Latitude } \\
\text { (DMS) }\end{array}$ & $\begin{array}{c}\text { Longitude } \\
\text { (DMS) }\end{array}$ & $\begin{array}{c}\text { Drainage } \\
\text { area } \\
\left(\mathrm{mi}^{2}\right)\end{array}$ \\
\hline 374755086090401 & Big Spring - F15CS004 & GW & $37^{\circ} 47^{\prime} 55^{\prime \prime}$ & $86^{\circ} 09^{\prime} 04^{\prime \prime}$ & -- \\
\hline 374846086154101 & Ross Karst Window - F14DS003 & GW & $37^{\circ} 48^{\prime} 46^{\prime \prime}$ & $86^{\circ} 15^{\prime} 41^{\prime \prime}$ & -- \\
\hline 374813086171501 & Flat Rock Spring - F14DS005 & GW & $37^{\circ} 48^{\prime} 13^{\prime \prime}$ & $86^{\circ} 17^{\prime} 15^{\prime \prime}$ & -- \\
\hline 374847086172901 & Fiddle Spring - F14DS007 & GW & $37^{\circ} 48^{\prime} 47^{\prime \prime}$ & $86^{\circ} 17^{\prime} 29^{\prime \prime}$ & -- \\
\hline 375209086224001 & Boiling Spring - F14CS002 & GW & $37^{\circ} 52^{\prime} 09^{\prime \prime}$ & $86^{\circ} 22^{\prime} 40^{\prime \prime}$ & -- \\
\hline 03303195 & Sinking Creek at Rosetta, Ky. & SW & $37^{\circ} 47^{\prime} 47^{\prime \prime}$ & $86^{\circ} 16^{\prime} 25^{\prime \prime}$ & 36 \\
\hline 03303205 & Sinking Creek near Lodiburg, Ky. & SW & $37^{\circ} 52^{\prime} 06^{\prime \prime}$ & $86^{\circ} 23^{\prime} 16^{\prime \prime}$ & 125 \\
\hline
\end{tabular}

\section{Sampling Methods}

Representative water-quality and suspended-sediment samples from the Sinking Creek at Rosetta and Sinking Creek near Lodiburg sites were collected by means of the equalwidth-increment (EWI) method, in which depth-integrated samples were collected at equal distances across the entire stream width and composited (Edwards and Glysson, 1998). Dip samples were collected from the springs for water-quality and suspended-sediment analyses. All sampling material was constructed of Teflon or fluorinated plastic to minimize contamination. Equipment used to collect and process nutrient and pesticide samples was precleaned with a 0.1-percent nonphosphate detergent, triple rinsed with tap water, acid rinsed with 5-percent hydrochloric acid for 30 minutes (nonmetal equipment only), triple rinsed with deionized water, rinsed with certified pesticide-free methanol, air dried, and stored in a dust-free environment prior to sample collection (Webb and others, 1999).

Water samples for dissolved nutrients were filtered using a 0.45 -micrometer $(\mu \mathrm{m})$ pore-size filter that was pre-rinsed with deionized water and filtered native stream water and collected in the appropriate bottle types. Whole-water (unfiltered) nutrient samples were preserved using 1 milliliter $(\mathrm{mL})$ of $4.5 \mathrm{~N}$ sulfuric acid. Samples for pesticides were pumped through Teflon tubing and filtered through a 142-millimeter $(\mathrm{mm})$ diameter, $0.7-\mu \mathrm{m}$ pore size, borosilicate glass-fiber filter placed in a stainless-steel filter unit (Sandstrom, 1995). The filtered water was collected in amber-colored glass bottles and chilled for later analysis of pesticides. Both the glass-fiber filters and the glass bottles had been baked at $450^{\circ} \mathrm{C}$ in a muffle furnace for a minimum of 2 hours. All nutrient and pesticide samples were chilled and shipped on ice to the USGS National Water Quality Laboratory (NWQL) in Lakewood, Colorado, for analysis. Suspended-sediment samples were analyzed by the USGS Kentucky Water Science Center (KWSC) Sediment Laboratory in Louisville, Kentucky.
Field measurements of stream discharge, air temperature, barometric pressure, water temperature, specific conductance, $\mathrm{pH}$, concentrations of $\mathrm{DO}$, and turbidity were measured at the time of sampling. Alkalinity and bicarbonate were determined by titrating filtered sample water with $0.16 \mathrm{~N}$ sulfuric acid using a digital titrator. Discharge was measured according to standard USGS guidelines as described by Rantz and others (1982).

A continuously recording water-quality monitor with a 15-minute-record interval was installed at the USGS streamflow-gaging station on Sinking Creek near Lodiburg (station number 03303205) on May 25, 2004. Water-quality properties measured with the monitor from May through November 2004 included water temperature, specific conductance, $\mathrm{pH}$, and DO. Measurements were transmitted every 4 hours via satellite to the USGS KWSC in Louisville, Kentucky, and were made available in near-real time on the World Wide Web at URL http//ky.water.usgs.gov/. The water-quality monitor was inspected onsite by USGS personnel approximately every 3 to 4 weeks to maintain calibration. Guidelines and standard operating procedures for maintaining the site and reporting the data are described in Wagner and others (2000).

\section{Analytical Methods}

The USGS NWQL analyzed the water-quality samples for nutrients and pesticides. Water-quality samples for dissolved (filtered) and suspended (unfiltered) species of nitrogen and phosphorus, listed in laboratory schedule 1682, were analyzed by colorimetric methods (Fishman, 1993; Patton and Truitt, 1992; U.S. Environmental Protection Agency, 1993). These analyses quantified sample concentrations of dissolved nitrite plus nitrate, dissolved ammonia (ammonia plus ammonium), dissolved orthophosphate, and total phosphorus. Concentrations of nutrients discussed in this report represent their concentrations expressed as either nitrogen or phosphorus. For 
example, a concentration of nitrate expressed as 10 milligrams per liter $(\mathrm{mg} / \mathrm{L})$ refers to a concentration of nitrate of $10 \mathrm{mg} / \mathrm{L}$ as nitrogen.

Pesticide samples (laboratory schedule 2001) were analyzed using capillary-column gas chromatography/mass spectrometry (GC/MS) with selected-ion monitoring (Zaugg and others, 1995). Concentrations of pesticides were reported by the NWQL with appropriate qualifiers to indicate analytical limitations. Analytical data from the NWQL were reported as "less than" when a pesticide was not detected or not present at the method detection limit (MDL). The MDL is defined as the minimum concentration of a substance that can be identified, measured, and reported with 99-percent confidence that the compound concentration is greater than zero (Wershaw and others, 1987). When the presence of a pesticide was detected and quantified in the sample, but the reported value was below the MDL, the concentration was identified as an estimated value and footnoted in tables 2 and 3 .

The USGS KWSC in Louisville, Kentucky, analyzed the suspended-sediment samples by filtering samples through a pretared $0.45-\mu \mathrm{m}$ membrane filter. The filtrate was rinsed with deionized water to remove salts, and the insoluble material and filter were dried at $103^{\circ} \mathrm{C}$ and weighed (Fishman and Friedman, 1989).

\section{Pesticide Results}

Detections and concentrations of pesticides in streams are affected by many factors, including the amount of pesticide used, the environmental persistence of the pesticide, and the analytical methods used. The most commonly detected pesticides (atrazine, simazine, and metolachlor) were among the most heavily applied in the karst terrane of the Sinking Creek Basin. A total of approximately $48,500 \mathrm{lb}$ of atrazine, $9,600 \mathrm{lb}$ of metolachlor, and 9,500 lb of simazine were applied to corn in Breckinridge, Hardin, and Meade Counties based on estimated-use data from 2002 applications. These estimates were calculated from agricultural inputs obtained by multiplying the pesticide application rates, the percentage of crop receiving pesticide application, and the county-level, crop-acreage data from the 2002 Census of Agriculture (National Agricultural Statistics Service, 2003). Pesticide application rates and treatment percentages were obtained from a 2003-04 survey by the Kentucky Agricultural Statistics Service (2004). Pesticide detections occurred most frequently in the spring to early summer months (April-June) when agricultural pesticides typically are applied. A common method reporting limit (MRL) of 0.01 micrograms per liter $(\mu \mathrm{g} / \mathrm{L})$ was used to compare the detection frequencies of pesticides having different MRLs. The use of a common reporting limit allows the comparison among pesticide compounds by bringing the data to a common reference point. Of the 52 pesticides analyzed, 14 were detected above the adjusted MRL of $0.01 \mu \mathrm{g} / \mathrm{L}$. Samples from all seven sites had detectable concentrations of at least one pesticide.

Herbicides were detected more frequently than insecticides. Eleven of the 14 pesticides detected in water were herbicides. The commonly applied herbicides-atrazine, simazine, metolachlor, acetochlor, and prometon — were found throughout the basin. Atrazine, one of the most commonly used herbicides in Sinking Creek for row-crop agriculture, was detected in all samples (fig. 3). Almost 88 percent of the atrazine samples were in the 0.1 to $1.0 \mu \mathrm{g} / \mathrm{L}$ range. The pesticide-transformation compound, deethylatrazine, was detected in 98 percent of the samples. Pesticide-transformation compounds are more water soluble than their parent compounds. For example, Mills and Thurman (1994) found that one of the transformation compounds of the parent compound atrazine-deethylatrazine—-sorbs less strongly to soils than does its parent compound. The toxicity of pesticide-transformation compounds is unknown (U.S. Geological Survey, 1999). Simazine, metolachlor, and acetochlor were detected in more than 35 percent of the samples. Atrazine and simazine (rowcrop herbicides) had the highest detected concentrations in the basin at 4.92 and $2.28 \mu \mathrm{g} / \mathrm{L}$, respectively (table 2 and fig. 4). The highest concentrations of pesticides occurred in the spring during storm runoff. Less frequently detected herbicides were alachlor, metribuzin, napropamide, pendimethalin, propachlor, and propanil.

The insecticides carbofuran and malathion were the only insecticides detected at any of the sites; they were detected infrequently. Malathion was detected in 4 percent of the samples and was detected most frequently in August; the maximum concentration was $0.21 \mu \mathrm{g} / \mathrm{L}$. Malathion is used in agriculture, residential gardens, and in public-health pestcontrol programs to control mosquito populations. Carbofuran was detected in only one sample in May. The lower use relative to herbicides and the application during periods of reduced runoff probably account for lower detection rates and low concentrations of insecticides in the basin.

Concentrations of most of the pesticides analyzed were less than detection limits (table 2). Median concentrations of the most frequently detected pesticides (acetochlor, atrazine, metolachlor, prometon, and simazine) ranged from $0.008 \mu \mathrm{g} / \mathrm{L}$ for acetochlor to $0.114 \mu \mathrm{g} / \mathrm{L}$ for atrazine for all samples collected during this study (table 2). The median concentrations of the two insecticides detected were less than their detection limits. 
Pesticide Results 7

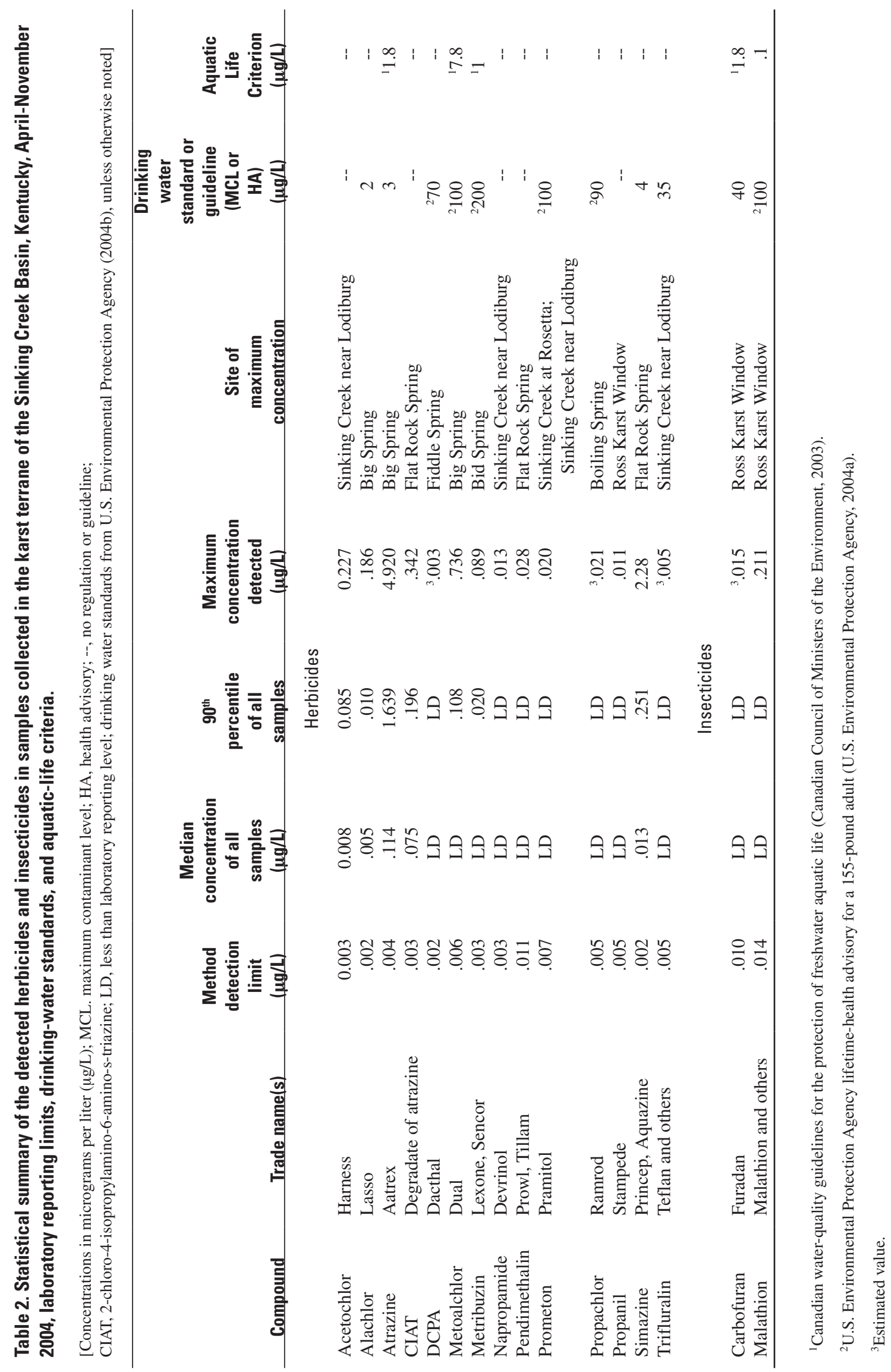


Table 3. Statistical summary of concentrations of nitrogen, phosphorus, and sediment in the karst terrane of the Sinking Creek Basin, Kentucky, April-November 2004.

$[<$, less than $]$

\begin{tabular}{|c|c|c|c|c|}
\hline \multirow[b]{2}{*}{ Constituent } & \multirow[b]{2}{*}{$\begin{array}{c}\text { Number } \\
\text { of } \\
\text { samples }\end{array}$} & \multicolumn{3}{|c|}{ Concentration, in milligrams per liter } \\
\hline & & Minimum & Median & Maximum \\
\hline & & \multicolumn{3}{|c|}{ Big Spring - F15CS004 } \\
\hline Ammonia, as nitrogen & 7 & $<0.04$ & $<0.04$ & 0.14 \\
\hline Nitrite plus nitrate, as nitrogen & 7 & 1.2 & 2.0 & 3.9 \\
\hline Total phosphorus, as phosphorus & 6 & .04 & .09 & .34 \\
\hline Orthophosphate, as phosphorus & 7 & .03 & .04 & .15 \\
\hline \multirow[t]{2}{*}{ Suspended sediment } & 7 & 1 & 7 & 153 \\
\hline & & \multicolumn{3}{|c|}{ Ross Karst Window - F14DS003 } \\
\hline Ammonia, as nitrogen & 6 & $<.04$ & $<.04$ & $<.04$ \\
\hline Nitrite plus nitrate, as nitrogen & 6 & .42 & 1.5 & 2.4 \\
\hline Total phosphorus, as phosphorus & 6 & .06 & .11 & .41 \\
\hline Orthophosphate, as phosphorus & 6 & .04 & .05 & .09 \\
\hline \multirow[t]{2}{*}{ Suspended sediment } & 6 & 6 & 20 & 581 \\
\hline & & \multicolumn{3}{|c|}{ Flat Rock Spring - F14DS005 } \\
\hline Ammonia, as nitrogen & 7 & $<.04$ & $<.04$ & $<.04$ \\
\hline Nitrite plus nitrate, as nitrogen & 7 & .76 & 1.6 & 2.5 \\
\hline Total phosphorus, as phosphorus & 7 & .06 & .09 & .3 \\
\hline Orthophosphate, as phosphorus & 7 & .03 & .05 & .12 \\
\hline \multirow[t]{2}{*}{ Suspended sediment } & 7 & 3 & 20 & 138 \\
\hline & & \multicolumn{3}{|c|}{ Fiddle Spring - F14DS007 } \\
\hline Ammonia, as nitrogen & 6 & $<.04$ & $<.04$ & $<.04$ \\
\hline Nitrite plus nitrate, as nitrogen & 6 & .4 & 1.3 & 2.1 \\
\hline Total phosphorus, as phosphorus & 6 & .06 & .08 & .31 \\
\hline Orthophosphate, as phosphorus & 6 & .03 & .05 & .19 \\
\hline \multirow[t]{2}{*}{ Suspended sediment } & 6 & 6 & 15 & 253 \\
\hline & & \multicolumn{3}{|c|}{ Boiling Spring - F14CS002 } \\
\hline Ammonia, as nitrogen & 7 & $<.04$ & $<.04$ & $<.04$ \\
\hline Nitrite plus nitrate, as nitrogen & 7 & .47 & 1.3 & 2.2 \\
\hline Total phosphorus, as phosphorus & 7 & .07 & .11 & .45 \\
\hline Orthophosphate, as phosphorus & 7 & .02 & .06 & .08 \\
\hline \multirow[t]{2}{*}{ Suspended sediment } & 7 & 7 & 31 & 409 \\
\hline & & \multicolumn{3}{|c|}{03303195 - Sinking Creek at Rosetta, Kentucky } \\
\hline Ammonia, as nitrogen & 7 & $<.04$ & $<.04$ & $<.04$ \\
\hline Nitrite plus nitrate, as nitrogen & 7 & .21 & .81 & 1.2 \\
\hline Total phosphorus, as phosphorus & 7 & .023 & .037 & .25 \\
\hline Orthophosphate, as phosphorus & 7 & ${ }^{\mathrm{e}} .003$ & .01 & .101 \\
\hline \multirow[t]{2}{*}{ Suspended sediment } & 7 & 3 & 11 & 306 \\
\hline & & \multicolumn{3}{|c|}{03303205 - Sinking Creek near Lodiburg, Kentucky } \\
\hline Ammonia, as nitrogen & 8 & $<.04$ & $<.04$ & $<.04$ \\
\hline Nitrite plus nitrate, as nitrogen & 8 & .35 & 1.3 & 2.2 \\
\hline Total phosphorus, as phosphorus & 8 & .07 & .10 & .42 \\
\hline Orthophosphate, as phosphorus & 8 & .01 & .05 & .07 \\
\hline Suspended sediment & 10 & 5 & 87 & 1,490 \\
\hline
\end{tabular}

${ }^{e}$ Estimated value. 


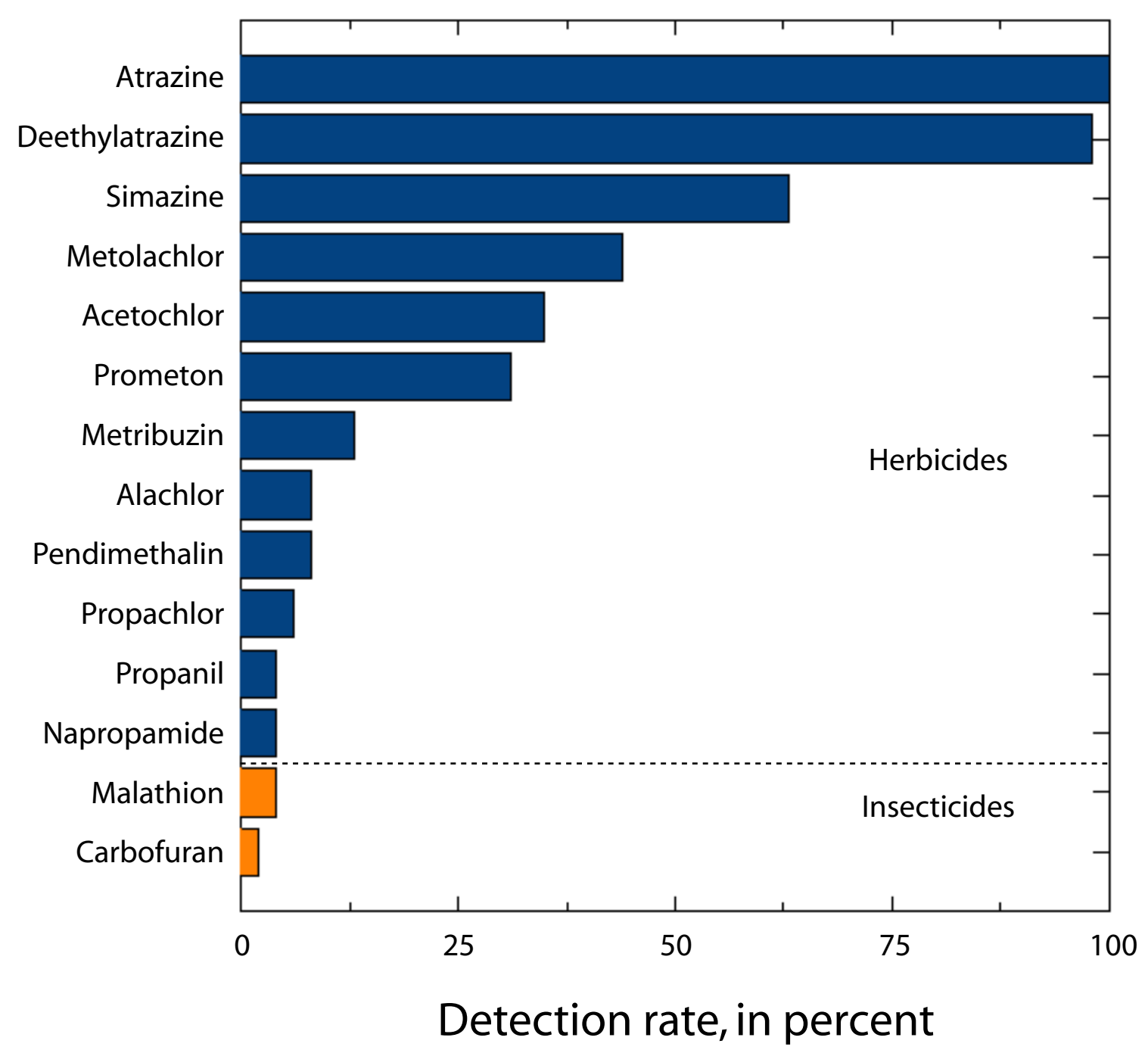

Figure 3. Pesticides most frequently detected in all samples collected at seven sites in the karst terrane of the Sinking Creek Basin, Kentucky, 2004. 

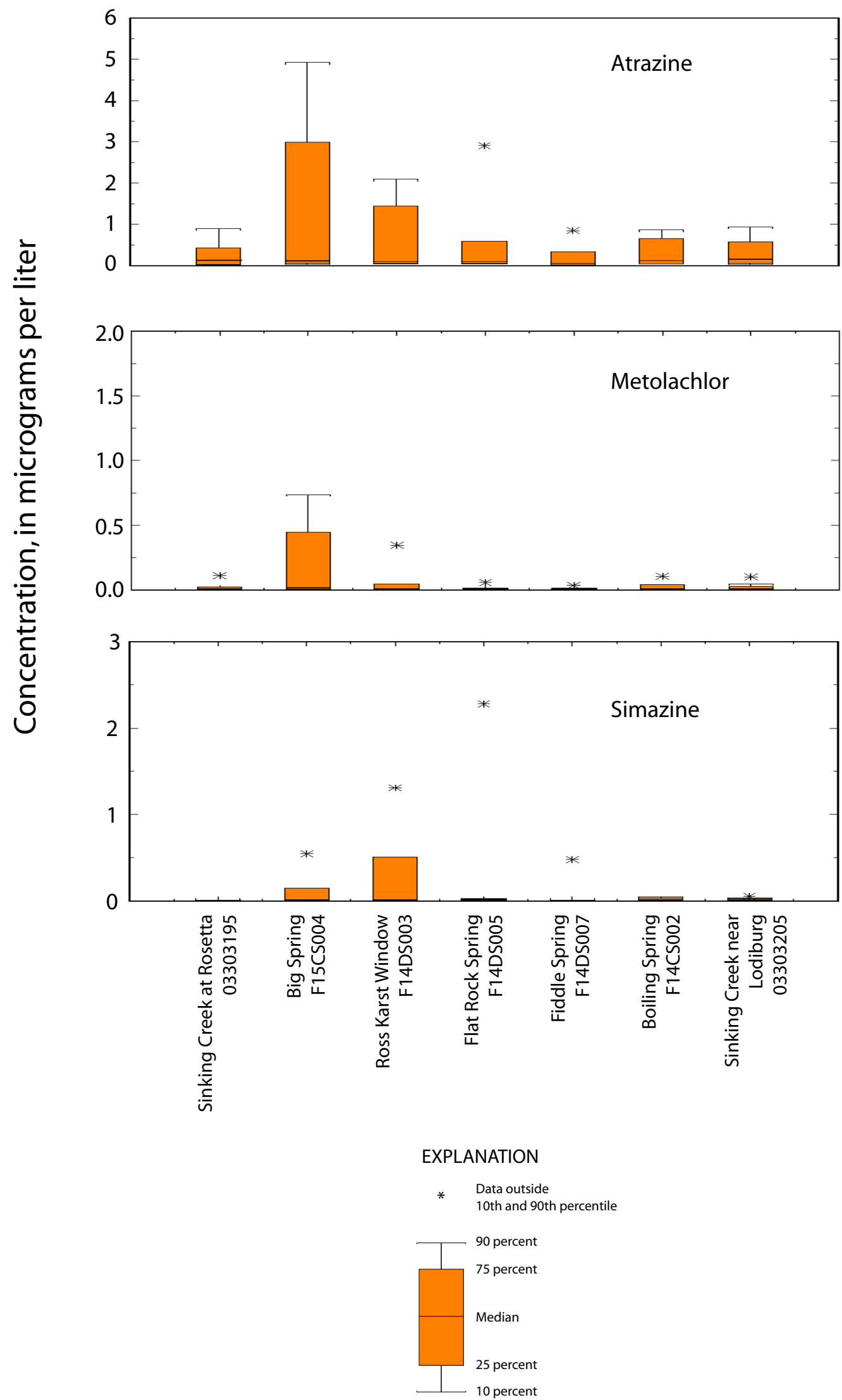

Figure 4. Concentrations of atrazine, metolachlor, and simazine at the seven sampling sites in the karst terrane of the Sinking Creek Basin, Kentucky, study area, 2004. 
The U.S. Environmental Protection Agency (USEPA) has developed water-quality standards and guidelines for some compounds that can have adverse effects on human health and aquatic organisms. The standards and guidelines (also known as maximum contaminant levels (MCLs)) established by the USEPA pertain to finished drinking water; however, the MCL values provide comparison with sampled concentrations (U.S. Environmental Protection Agency, 2004a). Aquaticlife criteria provide for the protection of aquatic organisms for short-term (acute) and long-term (chronic) exposures to chemical compounds. In certain instances, Canadian guidelines were used for comparisons when other criteria were unavailable (International Joint Commission Canada and United States, 1977; Canadian Council of Ministers of the Environment, 2003). Table 2 shows concentrations of detected pesticides and their relation to drinking-water criteria and aquatic-life criteria. No Federal drinking-water criteria have been established for many of the compounds detected including pesticide degradates. Concentrations of atrazine exceeded the USEPA's MCL of $3 \mu \mathrm{g} / \mathrm{L}$ in 4 percent of the samples.

\section{Nutrient Results}

Nutrients, such as nitrogen and phosphorus, are necessary for plant and animal life; in excessive quantities they can accelerate the growth of aquatic plants and cause algal blooms. Excessive aquatic growth may result in unsuitable habitat conditions for aquatic animals and can interfere with recreational activities such as fishing, swimming, and boating. Decomposition of aquatic-plant growth can cause odor and taste problems in drinking-water supplies and can consume DO, which can adversely affect aquatic life.

Nitrogen in streams can originate from numerous point and nonpoint sources. The major sources of nitrogen into streams are wastewater-treatment plants, septic tanks, feed-lot discharges, and fertilizers from agricultural and residential areas. Concentrations of nitrate greater than $10 \mathrm{mg} / \mathrm{L}$ in drinking water can have adverse human-health effects. Concentrations of nitrite plus nitrate ranged from 0.21 to $3.9 \mathrm{mg} / \mathrm{L}$ at the 7 sites (table 3 and fig. 5). The highest concentration of nitrite plus nitrate of $3.9 \mathrm{mg} / \mathrm{L}$ was observed at Big Spring. The lowest concentration of nitrite plus nitrate of $0.21 \mathrm{mg} / \mathrm{L}$ was observed at Sinking Creek at Rosetta. The median concentration of nitrite plus nitrate for all sites sampled was $1.5 \mathrm{mg} / \mathrm{L}$. Big Spring had the highest median nitrogen concentration (2.0 mg/L). Ammonia was detected in only one sample (Big Spring).
Phosphorus is a common element in rocks; other sources of phosphorus include sewage effluent, detergents, and leachates from septic tanks. Although there is no established aquatic-life criterion for total phosphorus, the USEPA recommends a maximum concentration of total phosphorus of $0.1 \mathrm{mg} / \mathrm{L}$ to discourage excessive growth of aquatic plants and algae. Concentrations of total phosphorus in 42 percent of the samples were greater than $0.1 \mathrm{mg} / \mathrm{L}$. The median concentration of total phosphorus for all sites sampled was $0.09 \mathrm{mg} / \mathrm{L}$. Concentrations of orthophosphates ranged from $<0.006$ to $0.192 \mathrm{mg} / \mathrm{L}$ (table 3). The highest concentration of orthophosphorus was observed at Fiddle Spring (0.192 mg/L). Sources of orthophosphorus include weathering of soils and wastewater-treatment-plant discharge.

\section{Suspended Sediment Results}

Suspended sediment is all particulate matter suspended in the water column resulting from streambed resuspension, rock weathering, and soil erosion. Concentrations of suspended sediment are affected by natural conditions (streambank erosion, steep slopes, and forest fires) and anthropogenic activities (construction, mining, and certain agricultural practices).

High concentrations of suspended sediment can cause habitat destruction and limit light penetration throughout the water column. In addition, suspended sediment plays a major role in the transport and fate of contaminants. Contaminants may sorb onto the surface of the suspended sediments and be transported and deposited into other areas downstream.

Concentrations of suspended sediment generally were low in the karst terrane of the Sinking Creek Basin (table 3 and fig. 6); the median concentration of suspended sediment for all sites sampled was $23 \mathrm{mg} / \mathrm{L}$. The highest concentration of suspended sediment $(1,486 \mathrm{mg} / \mathrm{L})$ was measured following a storm event at Sinking Creek near Lodiburg, Ky. 


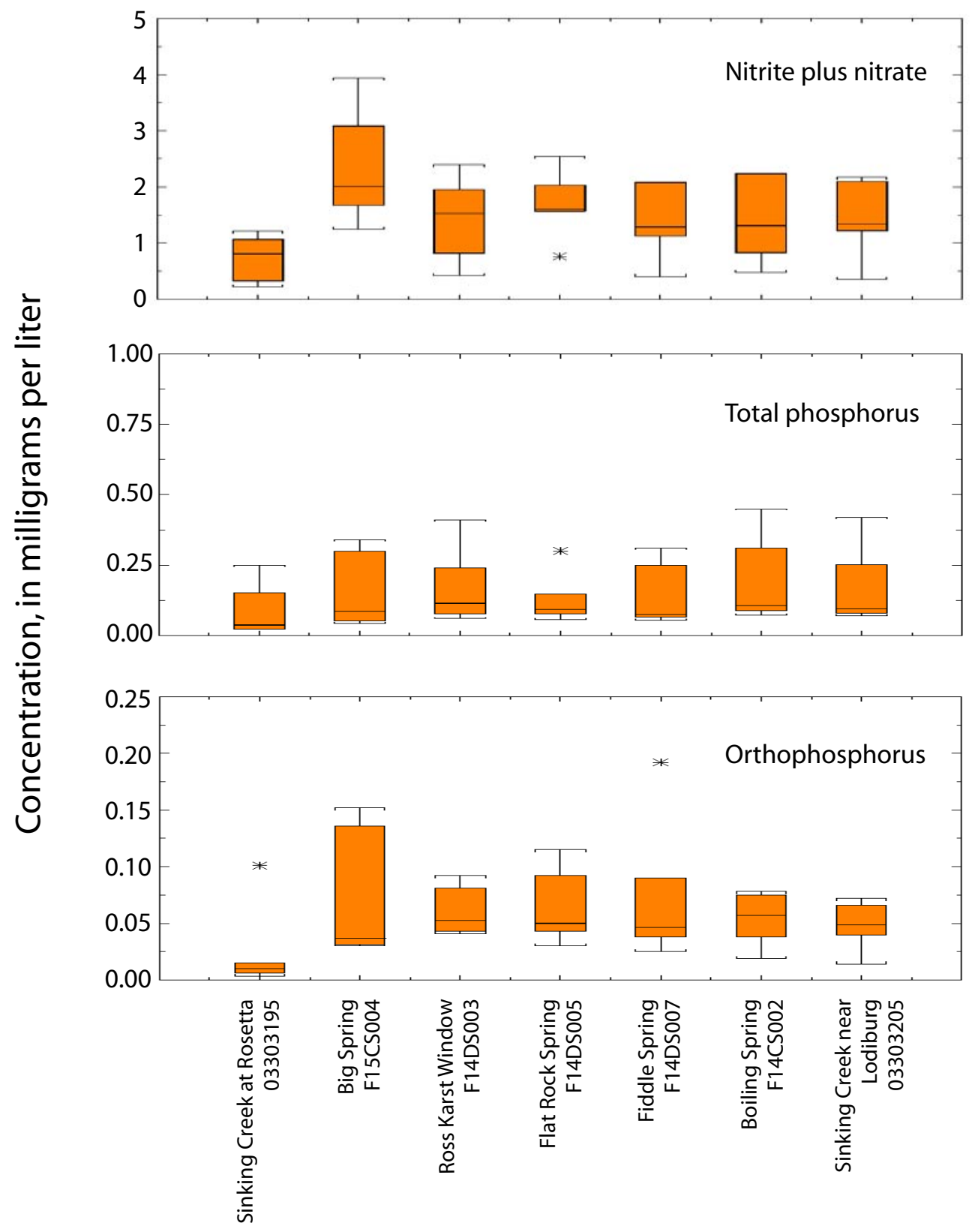

EXPLANATION

* Data outside

10th and 90th percentile

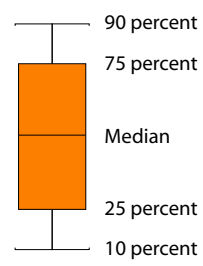

Figure 5. Concentrations of nitrite plus nitrate, total phosphorus, and orthophosphorus at the seven sampling sites in the karst terrane of the Sinking Creek Basin, Kentucky, study area, 2004. 

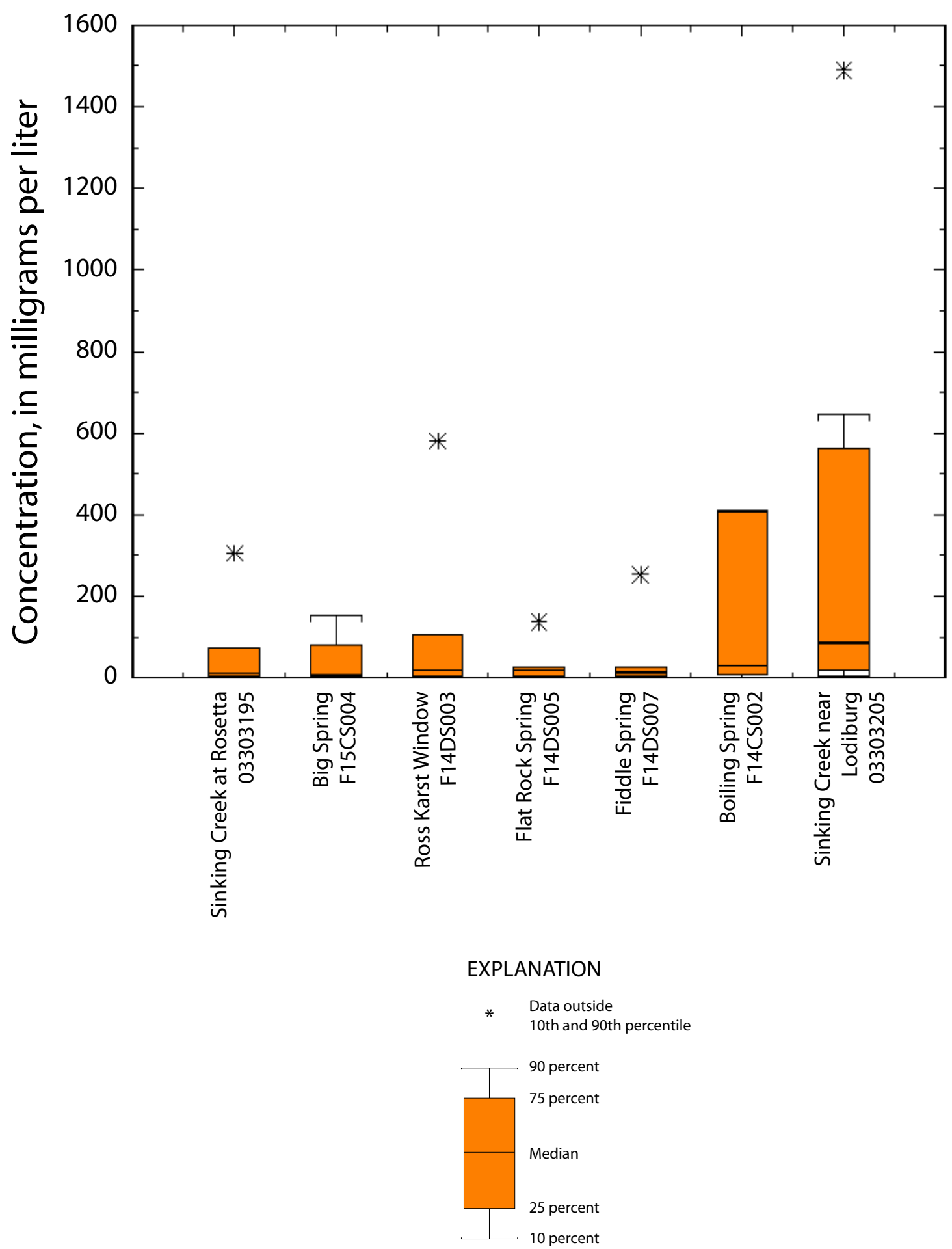

Figure 6. Concentrations of suspended sediment at the seven sampling sites in the karst terrane of the Sinking Creek Basin, Kentucky, study area, 2004. 


\section{Summary}

Pesticides, nutrients, and sediment are frequently detected in karst and are a threat to the degradation of drinking water because of erosion and leaching. Understanding the role bestmanagement practices play in protecting shallow ground water (karst) from human-induced activities (construction, logging, and certain agricultural activities) is fundamental to developing and implementing sound land-use policies. This is the case faced by resource managers in the karst terrane of the Sinking Creek Basin. In response to these issues, the U.S. Geological Survey, in cooperation with the Kentucky Department of Agriculture, began a study to investigate select pesticides, nutrients, and suspended sediment in the karst terrane of the Sinking Creek Basin (also known as Boiling Spring Basin). This is a 3-year study (2004-2006); however, only the 2004 water-quality and suspended-sediment results are presented in this report. A final report presenting all 3 years of data collection should be available in late 2007.

Water-quality and suspended-sediment samples were collected in streams and springs in the karst terrane of the Sinking Creek Basin, which is located in Breckinridge County and portions of Meade and Hardin Counties in Kentucky. Fortyeight water samples were collected at 7 sites (2 Sinking Creek main stem sites; 4 springs, and 1 karst window) from April to November 2004.

Most pesticides were present in low concentrations in 2004. Herbicides were detected more frequently than insecticides. Fourteen pesticides were detected of the 52 pesticides analyzed in the water samples. Of the 14 detected pesticides, 12 were herbicides and 2 were insecticides. The most commonly detected herbicides were those used on row crops. The herbicide, atrazine, was detected in 100 percent of the samples. Almost 88 percent of the atrazine samples were in the 0.1 to 1.0 micrograms per liter $(\mu \mathrm{g} / \mathrm{L})$ range. Four percent of the samples exceeded the atrazine maximum contaminant level for drinking water, which is $3.0 \mu \mathrm{g} / \mathrm{L}$. Deethylatrazine, a transformation compound of atrazine, was detected in 98 percent of the samples. Other herbicides including simazine, metolachlor, and acetochlor were detected in more than 35 percent of the samples. Only one nonagricultural herbicide, prometon, was detected in more than 30 percent of the samples. Malathion, the most commonly detected insecticide, was detected only in 4 percent of the samples followed by carbofuran (in 2 percent of the samples).

Concentrations of nitrite plus nitrate ranged from 0.21 to 3.9 milligrams per liter $(\mathrm{mg} / \mathrm{L})$ at the 7 sites. The median concentration of nitrite plus nitrate for all sites sampled was $1.5 \mathrm{mg} / \mathrm{L}$, which is below the USEPA's nitrate drinking water standard of $10 \mathrm{mg} / \mathrm{L}$. Concentrations of nitrite plus nitrate were higher in the springs than in the main stem of Sinking Creek.

The median concentration of total phosphorus for all sites sampled was $0.09 \mathrm{mg} / \mathrm{L}$. The highest median concentration of total phosphorus was found in the springs. Forty-two percent of the concentrations of total phosphorus at all seven sites exceeded the USEPA's recommended maximum concentration of $0.1 \mathrm{mg} / \mathrm{L}$. Concentrations of orthophosphate ranged from $<0.006$ to $0.192 \mathrm{mg} / \mathrm{L}$.

Concentrations of suspended sediment generally were low throughout the karst terrane of the Sinking Creek Basin; the median concentration of suspended sediment for all sites sampled was $23 \mathrm{mg} / \mathrm{L}$. The highest concentration of suspended sediment $(1,486 \mathrm{mg} / \mathrm{L})$ was measured following a storm event at Sinking Creek near Lodiburg, Ky.

\section{References Cited}

Barbash, J.E., and Resek, E.A., 1997, Pesticides in ground water: distribution, trends, and governing factors: Lewis Publishers, Pesticides in the Hydrologic System series, v. 2, $590 \mathrm{p}$.

Becher, K.D., Schnoebelen, D.J., and Ackers, K.B., 2000, Nutrients Discharged to the Mississippi River from Eastern Iowa Watersheds, 1996-1997: Journal of American Water Resources Association, v. 36, no. 5, p. 161-173.

Canadian Council of Ministers of the Environment, 2003, Summary of existing Canadian environmental quality guidelines, online at <http://www.ccme.ca/assets/pdf/e1_062. $p d f>$, accessed August 23, 2005.

Edwards, T.K., and Glysson, G.D., 1998, Field methods for measurement of fluvial sediment, U.S. Geological Survey Techniques of Water-Resources Investigations, book 3, chap. C2, 80 p.

Fishman, M.J., ed., 1993, Methods of analysis by the U.S. Geological Survey National Water Quality Laboratory-Determination of inorganic and organic constituents in water and fluvial sediments: U.S. Geological Survey Open-File Report 93-125, 217 p.

Fishman, M.J., and Friedman, L.C., 1989, Methods for determination of inorganic substances in water and fluvial sediments: U.S. Geological Survey Techniques of WaterResources Investigations, book 5, chap. A1, 545 p.

Goolsby, D.A., and Battaglin, W.A., 1997, Sources and Transport of Nitrogen in the Mississippi River Basin: American Farm Bureau Federation workshop, St. Louis, Missouri, July 14-15, 1997, online at <http://wwwrcolka.cr.usgs.gov/ midconherb/st.louis.hypoxia.html>, accessed November 13, 2003.

International Joint Commission Canada and United States, 1977, New and revised Great Lakes water quality objectives-Volume II, An IJC report to the government of the United States and Canada: Windsor, Ontario, Canada, IJC. 
Kentucky Agricultural Statistics Service, 2004, Kentucky Agricultural Statistics, 2003-2004: Louisville, Ky., Kentucky Agricultural Statistics Service Annual Bulletin, 156 p.

Kentucky Division of Water, 2005, 2004 303(d) List of Waters for Kentucky, online at $\langle$ http $>/ / w w w$.water.ky.gov/>, accessed January 17, 2006.

Mills, M.S., and Thurman, E.M., 1994, Preferential dealkylation Reactions of S-Triazine Herbicides in the Unsaturated Zone: Environmental Science and Technology, v. 28, p. 600-605.

National Agricultural Statistics Service, 2003, 2002 Census of Agriculture, online at $<$ http://www.nass.usda.gov/Census of_Agriculture/index.asp $>$, accessed February 6, 2006.

National Oceanic and Atmospheric Administration, 1999, U.S. monthly precipitation for Cooperative and NWS sites, online at <http://www.ncdc.noaa.gov/oa/pub/data/coopprecip/kentucky.txt>, accessed August 23, 2005.

Patton, C.J., and Truitt, E.P., 1992, Methods of analysis by the U.S. Geological Survey National Water Quality Laboratory; determination of the total phosphorus by a Kjeldahl digestion method and an automated colorimetric finish that includes dialysis: U.S. Geological Survey Open File Report 92-146, $39 \mathrm{p}$.

Rantz, S.E., and others, 1982, Measurement and computation of streamflow-Volume 2, Computation and discharge: U.S. Geological Survey Water-Supply Paper 2175, 2 vol., $631 \mathrm{p}$.

Ray, J.A., Webb, J.S., and O'Dell, P.W., 1994, Groundwater Sensitivity Regions of Kentucky, online at http://kgsweb. uky.edu/download/wrs/sensitivity.pdf, accessed January 7 , 2006.

Sandstrom, M.W., 1995, Filtration of water-sediment samples for the determination of organic compounds: U.S. Geological Survey Water-Resources Investigations Report 95-4105, $13 \mathrm{p}$.

Schilling, K.E., and Thompson, C.A., 2000, Walnut Creek Watershed Monitoring Project, Iowa-Monitoring Water Quality in Response to Prairie Restoration: Journal of the American Water Resources Association, v. 36, no. 5, p. $1,101-1,117$.

U.S. Census Bureau, 2001, Census 2000 data for the state of Kentucky, online at <http://www.census.gov/census2000/ states/ky.html>, accessed August 23, 2005.
U.S. Environmental Protection Agency, 1993, Methods for the determination of inorganic substances in environmental samples-Phosphorus by automated colorimetry (method 365.1): EPA 600-R-93-100,

U.S. Environmental Protection Agency, 2004a, 2004 Edition of the drinking water standards and health advisories: U.S. Environmental Protection Agency, Office of Water, EPA-822-R-04-005, Winter 2004, online at <http://www. epa.gov/waterscience/criteria/drinking/>, accessed August 23, 2005.

U.S. Environmental Protection Agency, 2004b, National recommended water-quality criteria, online at $\langle h t t p: / / w w w$. epa.gov/waterscience/criteria/wqcriteria.html $>$, accessed August 23, 2005.

U.S. Geological Survey, 1999, The Quality of our Nation's Waters-Nutrients and Pesticides: U.S. Geological Survey Circular 1225, $82 \mathrm{p}$.

Viessman, W. Jr., Lewis, G.L., and Knapp, J.W., 1989, Introduction to hydrology (3d ed.): New York, Harper and Row Publishers, $780 \mathrm{p}$.

Wagner, R.J., Mattraw, H.C., Ritx, G.F., and Smith, B.A., 2000, Guidelines and standard procedures for continuous water-quality monitors-Site selection, field operation, calibration, record computation, and reporting: U.S. Geological Survey Water-Resources Investigations Report 00-4252, $53 \mathrm{p}$.

Webb, W.E, Radtke, D.B, and Iwatsub, R.T., 1999, Surfacewater sampling-collection methods at flowing-water and still-water sites, in Wilde, F.D., and Radtke, D.B., eds., 1999, Collection of water samples, in National field manual for the collection of water-quality data: U.S. Geological Techniques of Water-Resources Investigations, book 9, chap. A4.1, 36 p.

Wershaw, R.L., Fishman, M.J., Grabbe, R.R., and Lowe, L.E., eds., 1987, Methods for the determination of organic substances in water and fluvial sediments: U.S. Geological Survey Techniques of Water-Resources Investigations, book 5, chap. A3, $80 \mathrm{p}$.

Zaugg, S.D., Sandstrom, M.W., Smith, S.G., and Fehlberg, K.M., 1995, Methods of analysis by the U.S. Geological Survey National Water Quality LaboratoryDetermination of pesticides in water by $\mathrm{C}-18$ solid-phase extraction and capillary-column gas chromatography/mass spectrometry with selected-ion monitoring: U.S. Geological Survey Open-File Report 95-181, 60 p. 



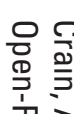
产 证

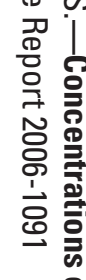

울

$\stackrel{8}{9}$

흥.

”े

흘

言

cs

을.

$\stackrel{\mathrm{D}}{\mathrm{E}}$

$\Xi$

言

옹

목

ิㅗํ

홍

景.

옹

商

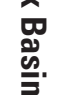

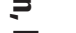

올

옹 